\title{
古代ギリシア神域の配置計画の発展に関する試論 THE DEVELOPMENT OF SITE PLANNING OF ANCIENT GREEK SANCTUARIES
}

\author{
伊藤 重 剛* \\ Juko ITO
}

\begin{abstract}
There have been discussions about the ancient Greek sanctuaries before the Hellenistic period that they had no principle of site planning. Especially those like Olympia, Delphi, etc., which had long tradition in the mainland Greece, in fact look like a jumble, mainly because the buildings were laid neither orthogonally nor pararelly each other, compared with Hellenistic regular planning. However, the present analyses of the plans would suggest us that the buildings in some of the sanctuaries were related each other through axes and the extended lines of the exterior walls. The building arrangement of this kind would have been predecessors of the Hellenistic symmetrical and axial planning of the sanctuaries.
\end{abstract}

Keywords : ancient Greece, sanctuary, site planning, Olympia, Cos 古代ギリシア，神域，配置計画, オリンピア，コス

\section{1.はじめに}

古代ギリシア・ローマの神域において，建物の配置の 手法は必ずしも一様ではない。しかしながら,アルカイッ ク期からローマ期までの長い期間には，その配置方法に ひとつの発展の傾向といったものが観察される。それは アルカイック・クラシック期の必ずしもひとつの定まっ た方法のないような，いわば地形に合わせた自由な配置 から，ヘレニズム・ローマ期の明らかにひとつの一貫し たマスタープランによって軸線性, 左右対称性, 正面性 をもつ建築の複合体としての配置への発展であった。そ して紀元後 2 世紀頃の中近東一帯を中心に分布するバー ルベック，ジェラシュなどにある巨大神域が，この発展 の最終的な形であった。

こうした軸線計画にもとづいた整然たる配置計画は, ヨーロッパの建築史を考える上で，重要な意味をもって いる。というのは，例えばルネッサンス時代のヴィス夕 を意識したヴィラの計画, ヴェルサイユに代表されるバ ロックの宮殿之庭園の計画, 透視図的効果を生み出す都 市景観の作り方など，ルネッサンス以後の西洋建築にも 大きい影響を与えているからである。つまりルネッサン ス以後近代建築が始まる以前の西洋では，建物の配置に おける秩序の感覚とは軸線に基づいた計画であったと いっても過言ではなく，そのそもそもの起源はヘレニズ
ム建築にあり，それがローマ建築を介してルネッサンス に伝えられたのである。

これらヘレニズム・ローマ期の神域は，明らかに最初 から一つの複合建築として作られており，配置計画の意 図を明らかにすることが比較的容易で，筆者も旧稿でい くつかの分析を試みた1”。しかしながらアルカイック・ クラシック期から続くギリシアの伝統的な神域，とくに アテネのアクロポリス，デルフィ，オリンピア，デロス など古代ギリシアを代表するようなギリシア本土の神域 については，明確な配置の方法はいまだ解明されていな い。これらの神域の配置計画については従来の研究がい くつかあり，旧稿で報告しているので2，再度ここで詳 しく述べないが，スティルウェルのいうように，「神殿 は遠くから見えるように丘のような高みになった場所に 配置され，神域の入り口からは非軸線的に斜めに見られ るような角度で配置され，正面を東に向けられている」， という言葉に代表されるであろう ${ }^{3)}$ 。また「ギリシア都 市はいかにして作られたか』を書いたウィッチャーリは, 「ギリシア建築は，個々の建築としては調和のとれた比 例をもつ非常に優れた傑作であるが，それらを群として 見た場合，ごたごたした乱雑な配置となっている」とし ている4)。

こうした研究から,ヘレニズム以後の整然とした配置

本論文の一部は日本建築学会九州支部研究報告 第 31 号, 1989 年 3 月, 日本建築学会大会学術講演梗概集（中国），1990 年 10 月に発表した。

* 熊本大学工学部建築学科 講師・工博 Lecturer, Dept. of Architecture, Faculty of Engineering, Kumamoto Univ., Dr. Eng. 
計画は，純枠にギリシア的なものであると考えられてい るギリシア本土のアルカイック・クラシック期のそれと は，一見するところ無関係であるかのように思われる。 これらの神域においては,ヘレニズム期になってさえも， 明快なヘレニズム・ローマ期の神域の計画の特徽を示さ ないのである。その理由としてあげられるのは，これら の神域がミケナイ時代や幾何学時代から数百年もかかる ような長い期間にわたって，建設が断続的に行なわれた ため，全体をひとつの統一された原理によって，建築の 複合体を形成していくということが困難であったという ことや，長く伝わってきた各神殿や神祠の向きや位置な どが，時代が下がって建築的な発展をとげた後にもその まま保持されたため，ということなどが考えられる。

とはいっても，ヘレニズム期に出現した軸線的な平面 計画とその考え方が，アルカイック・クラシック期の配 置計画と全く無縁で, 突然出現したとも考えられない。 本稿ではまずアルカイック期からローマ期までの遗構が 残るオリンピアの神域と,クラシック期からヘレニズム 期にかけての遺構をもつコスのアスクレピオス神域につ いてその配置計画を分析する。さらにそのほかの神域に ついても，ヘレニズム以降とくに紀元前 2 世紀を境とし て，建物の配置が完全に軸線的，左右対称的な配置に変 貌していくまでの経過を，とくにプロピロン，祭壇及び 神殿の位置関係に注目して検討をこころみる。というの は，この三種類の建築は神域の中でもっとも基本的な建 物で,参詣者の動線や視線に対して大きい影響を与える， 神域内での建物の配置の上で非常に重要なものであるか らである。

\section{2. オリンピアの配置計画 (図一1)}

オリンピアはミケナイ時代のメガロンが発掘されてい るように年代的にも非常に古い時期まで遡り，全ギリシ ア的な行事であったオリンピック競技が行なわれた極め て重要な神域であり，ギリシアを代表する神域といって よい。ミケナイ時代以後も建設活動はアルカイック期か らローマ期まで途切れることなく続けられている。神域 はゼウス神殿やへラ神殿を中心として，スタディオン， パラエストラ，宿泊施設，ストア，宝庫など一連の建物 から構成され，アルティスと総称されている。ペロポネ ソス半島西側のクラデオス川に面した平坦な場所なので 地形からくる建物配置の困難さはとくに考えられない。

全体的な配置をみると，神域内の建物は，ペロピオン の門など一部を除いて, 神域の中央に東西に向けて配置 されたゼウス神殿を基準に，これと概ね平行かあるいは 直角方向に並ぶことを基本的に意図されていたと考えら れる。にもかかわらず一見して分かるとおり, 互いに厳 密に平行ないし直角に配置されている建物がほとんゼな いので，建物の配置は不規則と見られ，これまで配置に
関してとくに明確な原則がないとされてきたのは, 前述 したウィッチャーリの言のとおりである。しかし，平面 において建物と建物の位置関係に着目して子細に検討す ると，近接して建てられた二つの建物の間には，以下に 述べるような建物間の関係が見出された。

分析に使用した資料として，現在までに公刊された実 測図の中では最も精度の高い，クルティウスによる遺跡 現況実測図（A 2 版 6 枚組，縮尺 1/320）を用いた また建築年代の参考とするためマルウィッツによる遺跡 概説書の配置図および年表を参照した ${ }^{6)}$ 。以下の所見の うち建物どうしがなす角度については，クルティウスの 実測図を複写しこれを貼り合わせた図上で補助線を引 き, 30 分毎の目盛りのついた分度器を用いて著者が計 測した。建物の軸線や壁面の延長線などの見通し線が他 の建物の隅角部に当たるという点については，同様に図 上で考えられる幾種類もの補助線を引いて検討し，さら に現場で目測による確認を行なった。クルティウスの実 測図あるいは本文の記述中には, 遺構の出土状況が客観 的に図面化されあるいは記述されているだけで，こうし た角度の記述や分析等は一切なされていない。

1)，建物の外縁部の延長線と他の建物の出隅の一致

この例で最古のものは，ゼウス神殿（紀元前 457 年） とエコーホール(紀元前 4 世紀後期) の関係に見られる。 ゼウス神殿の東西軸とエコーホールの南北軸は互いに 93 度の角度をなしており, 完全に直角ではない。しか しゼウス神殿の南側の基壇の線を東に延長すると，工 コーホールの基壇南端に当たる。つまりエコーホールは, ゼウス神殿の南側基壇の延長線上に，その基壇の南端を 合わせて配置されている。

これと同じ関係は，エコーホールの建設とほぼ相前後 して建てられた，オリンピック関係者達の宿泊施設であ るレオニダイオン (紀元前 4 世紀後期) と, パラエスト

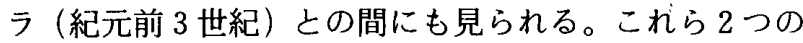
建物もそれらの南北軸が互いに 12 度の角度をなし，完 全に平行に配置されてはいない。これらは本来の神域の 領域からするとその周壁の外側に位置しているものであ るが, 建物の規模が大きく, 神域全体の配置の上で非常 な重要性をもっていたことが推測できる。

上の 2 例とは逆に既存の建物の出隅に新築の建物の外 縁の延長線を揃えた例が見られる。レオニダイオンの北 側基壇を延長すると，ゼウス神殿の基壇 2 段目の南東隅 に当たる。厳密には基壇最上段あるいは最下段でなく基 壇の 2 段目に合っているが、これはおそらく計測時ない し施工時の誤差（神殿からの距離約 $115 \mathrm{~m}$ の距離に対 して $0.6 \mathrm{~m})$ と思われる。レオニダイオン建設時には, 周辺にある最も大きい建物がゼウス神殿であったので， その方位は神殿を基準に決定された可能性が高い。

もうひとつこれと同様な関係が認められるのは,レオ 


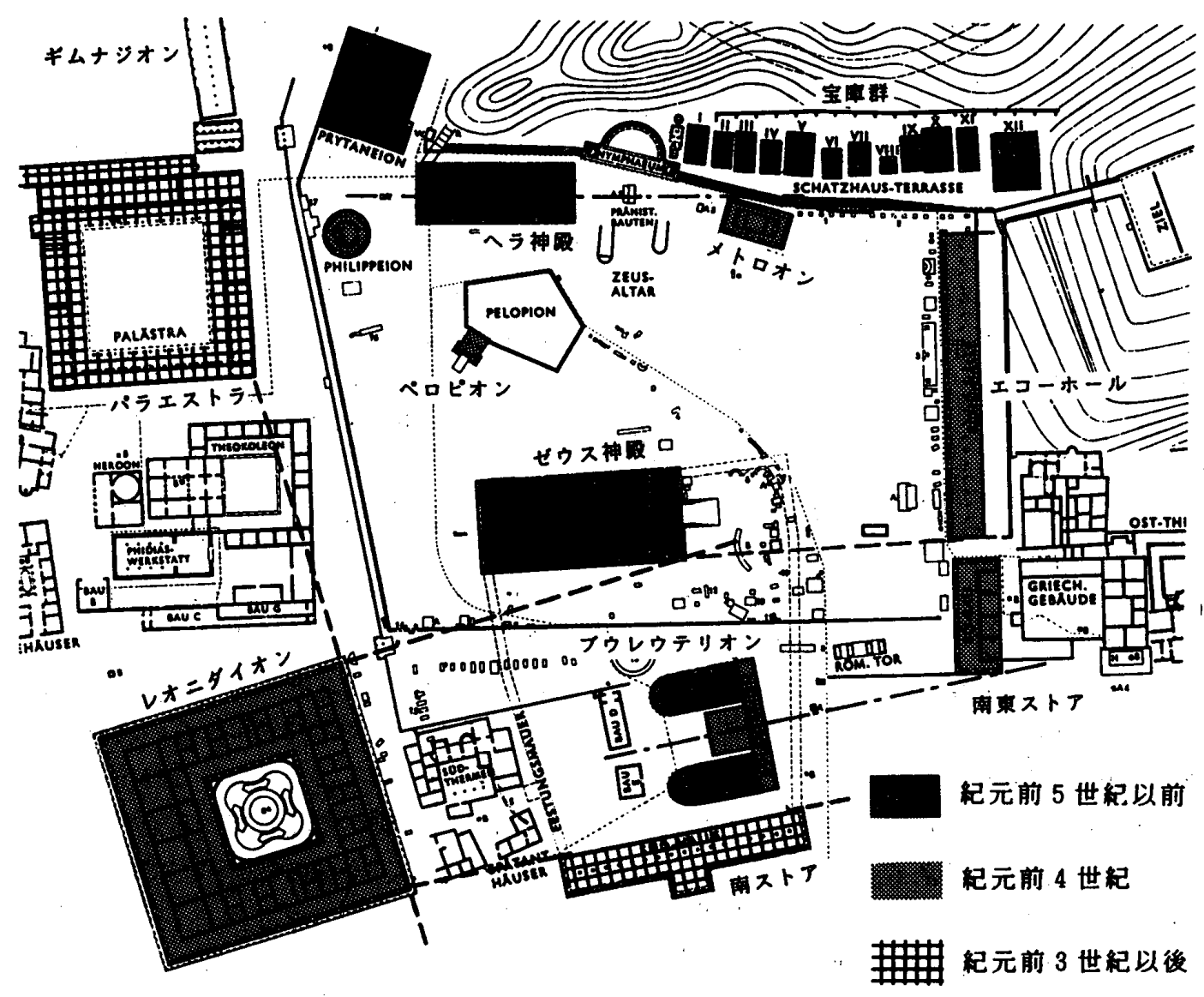

図一1 オリンピアのアルティス

ニダイオンと南ストア（紀元前 2 世紀）である。この二 つの建物についても，レオニダイオンの南北軸と南スト アの東西軸は互いに直角ではなく95 度の角度をなして いるが，南ストアの北側の壁の延長線はレオニダイオン の基壇南東隅に当たる。つまり前 2 世紀に南ストアが建 てられるとき，そのすぐ北隣にあるブウレウテリオンと 平行に配置しながら，その位置はレオニダイオンと空間 的な熬がりを保つように配置されたものと考えられる。

以上の例をまとめてみると，紀元前 5 世紀に神域内で 建築的にもっとも重要な建物であるゼウス神殿が建てら れると，その後紀元前 4 世紀にはこの神殿を基準にエ コーホールとレオニダイオンが配置されていることが分 かる。また紀元前 3 世紀以後はレオニダイオンを基準に パラエストラおよび南ストアが建てられていることが分 かる。

2）建物の軸線と他の建物の出隅の一致

紀元前 4 世紀になるとすぐ，メトロオンおよび南東ス トアが建設された。同時に南北に平行に並ぶ 2 棟のブウ レウテリオンが，正面に列柱廊を付加されて一つの複合 体となった。興味深いことに，この新しくされた複合体 としてのブウレウテリオンの軸線は，南東ストアの南東 の隅に当たる。また同時にメトロオンの北西の隅はへラ 神殿の軸線上に位置している。つまりこれら 4 棟の建物 は，それぞれ一方の建物の軸線上にもう一つの建物の出
隅がのるように，配置されているのである。

オリンピアの建物配置に認められるこれらの現象は, 建築家などによって意図されたものではなく，全くの偶 然が重なった結果のようにも見える。しかし単純に確率 の問題として見ても，こうしたある建物の軸線上あるい は特定の線の延長上に，別の建物の隅角部が偶然のった り，あるいはその逆の現象が起こる可能性は非常に少な い。軸線あるいは壁の延長線といっても実際には幅のあ る線であったり，敷地条件や建物の形も考慮されなけれ ばならないので,もちろん理論そのままには行かないが, とにかくこの確率は非常に低いものと考えられる。した がって，これらの配置は一見不規則に見えながらも，こ うした意図によって計画されていたものと推測されるの である。

上で見たようにこのような手法はオリンピアでは紀元 前 4 世紀以後に顕著に見られるが，コスやペルガモンな ビ他のヘレニズム期の神域にも散見されるので, 今後そ れらと比較検討する必要がある。紀元前 2 世紀頃になる と, マグネシアのアルテミス神域など完全に左右対称の 軸線計画が出現するが，オリンピアに見られる軸線や外 縁線を意識した建物の配置は，それへ発展する前段階で あると考えられる。 
3. コスのアスクレピオス神域の配置計画 (図-2)

コス島のアスクレピオス神域の発掘之研究は, 19 世 紀から 20 世紀初頭にかけて行なわれ，報告書がヘル ツォークによって 1932 年に出版されている。本稿の分 析に用いた図面は，報告書の中の二枚の配置図（縮尺約 $1 / 1100$ 及び約 $1 / 750)$ である71。その後の調査はなされ ておらず，これ以上に大きい縮尺ないし精度の図面は， 現在のとこう発表されていない。したがってオリンピア の図と比較すると，分析の精度は覀いが，同じ方法で建 物の軸線や壁面の延長線などの補助線を図上に引き分析 を行なった。現場は階段で明らかなように斜面であり， しかも遺構はいずれも基壇までくらいしか残っていない ので，以下の所見が全て確認できたわけではないが，上 テラスの搉壁東端と下ストアの東翼廊の関係などは現場 で確認できた。

神域はコス島の緩斜面を利用して，三段のテラスを形 成するように配置されている。最初は祭壇が中テラスに 紀元前 4 世紀中頃に建てられ，その後紀元前 3 世紀にな り上テラスと下テラスにそれぞれコの字型のストアが向 かい合って建てられた。この段階で中テラスには祭壇の 前に神殿 B と神官の住宅が建てられた。紀元前 2 世紀に なると，上テラスの中央にドリス式の神殿が建てられ，

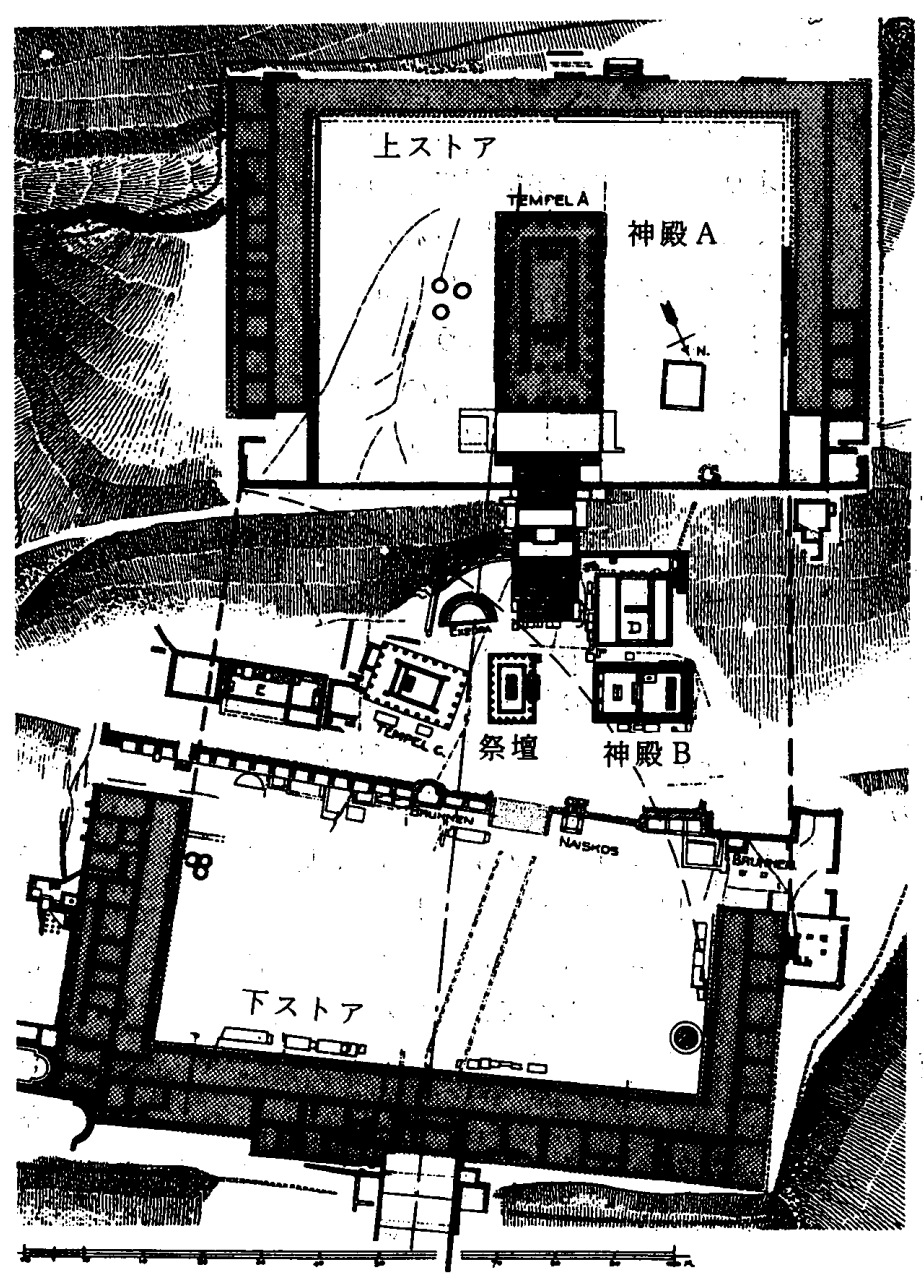

図一2 コスのアスクレピオス神域
木造だった上ストアも石造のものに建て替えられ，最終 的にほぼ現在遺跡に見られるような神域として形成され た。

最終的な紀元前 2 世紀の平面図をみると，神殿を上テ ラスの中央に置き，正面性，左右対称性，軸線性の強い ヘレニズム的な配置計画であることが分かる。しかしな がら，オリンピアでの建物配置と同様に，各テラスの上 の建物はお互いに少しずつ角度をなしており，完全に平 行ないし直角に配置されているわけではない。例えば上 ストアと下ストアの南北中心軸線は, 約 5 度の角度がつ けられており，しかもそれらは東西に互いにずれ合って いる。その明確な理由は分からないが，おそらく前身建 物の位置と方向ないし敷地の形状などの条件から生じた ものと思われる。また中テラスの古い神殿などの建物群 の配置を見ると、アルカイックからクラシック期にかけ てよく見られるような不規則な配置となっている。

しかしながら，オリンピアと同様平面図をよく検討す ると，担当した建築家は上ストアと下ストアをどうにか して関係づはうと努力していることが認められる。そ 扎は，上ス卜ア西翼廊の列柱の延長線は下ストア西翼廊 の南西の出隅に当たるし，また下ストア東翼廊の延長線 は上テラスの倣壁の東端に当たっていることから分か る。また，下ストアの東翼廊之主廊のなす角度は， 正確には直角を成さず内側に少し曲げられてお り；しかも下ストアの主廊の内法長さは，東翼廊 と主廊の交差する入隅部から東翼廊列柱の延長線 が上テラスの推壁に当たる点までの距離と等しい のである。東翼廊の東側には，東翼廊と主廊の角 度を直角にするのを阻むような敷地の条件は特に 認められないので，下ストアの位置と形状は，上 テラスとの位置関係を強く意識されているとしか 考えられない。下ストアの西翼廊の西側は，傾斜 の急な斜面になっており，この敷地条件のために 下ストアは少し東側にずらされ，しかもその軸線 は上テラスの軸線と少し:角度をなすように配置さ れたものと推測される。つまりこの神域の設計者 の意図は，敷地条件さえ整えば完全に上下のテラ スを平行に向かい合わせ，中心に軸線が通りその 軸線上に神殿を配置することであったと思われ る。

また神域への入り方としては，外側から下スト ア中央に取り付けられた大階段を上り，入り口 ホールを抜けて柱廊に出て，そこから下テラスの 中庭に出るようになっている。下テラスの入り口 の軸線は，当然ながら上テラスの神殿 $\mathrm{A}$ の軸線と は一致せず，中庭に入った見学者は神殿 $\mathrm{A}$ をや 斜めに見ることになり，この視角はプロピロンか ら神殿の正面と側面を同時に見るギリシアの伝統 
的な神域の配置計画に似ているとも言える。しかし，神 殿 $\mathrm{A}$ のファサードがほぼ正面に左右対称に見えるわけ で,ヘレニズム的な配置とも言える。

ともあれ,コスのアスクレピオス神域の配置をみると, アルカイック・クラシック期の神域と典型的なヘレニズ ム期の神域の中間の形を示しており，この配置が行なわ れた紀元前 3 世紀という配置計画における過渡期の時代 をよく表している。紀元前 2 世紀になると，マグネシア のアルテミス神域に見られるような, 完全に左右対称の 神域の配置となるのである。

\section{4. ギリシアの神域における建物配置のパターン}

以上オリンピアとコスの例で見たように，建物配置の 原則が明確に見えないような神域でも，建物の外壁の延 長線や軸線を通して, 建物どうしが関係し合っているこ とが認められる場合がある。もとよりアルカイック期か らヘレニズム後期の完全な左右対称形への神域の配置の 発展は必ずしも一様ではない。しかしながら, 建物配置 が必ずしも明確でないアルカイック・クラシック期の神 域について，このような観点から建物の配置をもう一度 再検討する必要がある。神域において建築的に重要な建 物としては, 神殿を第一として, プロピロンおよび祭壇 がこれに次ぎ，さらに後になるとこれらにストアが付加 された。ここでは建物に関する記述と平面図の得られる ギリシアの神域を全て検討し，これらプロピロンと神殿 及び祭壇の位置関係について，それぞれの建物の軸線を もとに分析した。そしてこの分析を通じて, 明らかにお 互いの位置を相互に規定し, あるいは規定されていると 思われる関係に着目して選び出し, 互いによ゙ういう関わ り方をしているか, その関わり方を以下の三つに分類す ることを試みた。

資料としては，それぞれの神域について公刊されたオ リジナルの発掘報告書あるいはその複写を用い, 分析方 法としてはオリンピア，コスの例と同様に行なった。困 面の精度ないし縮尺はまちまちで必ずしも一定ではない が，建物どうしの位置関係を定性的に論じる本稿の目的 には叶うものとした。

1) プロピロンの軸線と神殿ないし祭壇の軸線の屈折 (図一-3)

セリヌス、デメテールの祭壇前 5 世紀

ペルガモン ゼウスの大祭壇 “ 前 2 世紀

マグネシア アルテミス神殿及び祭壇

前 2 世紀

これらの神域では互いの建物の軸線が一本の直線とし て重ならず，ビちらかの建物のファサードの面で軸線が 折れ曲がっている例である。

シシリーのセリヌスにあるデメテール神域はその市域 から少し外れたところにあり，アクロポリスの外側の緩
い丘陵が平地に移る境目に位置している $(\text { 図一 } 7)^{8)}$ 。全 体の形はほぼ矩形であるが, 一部不整形の部分がある。 主建物である神殿は紀元前 6 世紀のもので, その前にあ る長い祭壇もほぼ同時期だと思われる。そしてこの神殿 と祭壇は, ほぼ矩形の神域に対して, 約 15 度の角度を なしている。プロピロンは神域の東壁と直交するような 配置で, 紀元前 5 世紀に作られたものである。したがっ て現在遺跡に見られる建物の配置は, 紀元前 5 世紀に形 成されたものと思われる。プロピロンの軸線は真っ直ぐ 正面の祭壇の中央を通るが, 祭壇自体はこの軸線とは角 度を成している。しかしながら神殿自体之の関係は，プ ロピロンの軸線が神殿の正面左隅に当たるという関係に なっている。このように，この神域は全体を貫くただ一 本の軸線を中心に全ての建物が配置されているわけでは ないが, プロピロンの軸線は祭壇の中央に向かうように 意識的に配置されている。

ペルガモンのゼウスの大祭壇9" は, ペルガモンの全盛 期であるエウメネス II 世（BC.197-159）の時代に建設 されている。神域全体の形はほぼ矩形であるが,上のア ゴラからアクロポリスに登る斜めの道に面しているた め, 入口側の神域の壁は結果的に全体の軸線に対して斜 めについている。プロピロンの位置と大きさは, 岩盤の 上に痕跡が残っているので確認できるが, 具体的にどん な建物であったかは不明である。しかしながら, 大祭壇 の軸線は明らかにプロピロンの正面中央を通っており， 大祭壇とプロピロンは互いに斜めに配置されているけれ ビも, プロピロンを通ってこの神域に一歩足を踏み入れ た人は，その身体をほんのわずか左に向けるだけで，大 祭壇の裹正面に向き合うことになる。

同様のことはマグネシアのアルテミス神域についても 言える101。ヘルモゲネスによって設計されたと言われて いるこの神域は,紀元前 2 世紀に入って建設が始められ, 完成したのは紀元前 130 年頃とされている。ここではプ ロピロンが, 隣接するアゴラを囲むストアに組み込まれ た形になっており，このストアが神域に対しで斜めに配 置されているため, プロピロンは神域全体の軸線に対し て斜めに配置された形になっている。しかしながら神域 全体の軸線はプロピロンの中央を通っており, プロピロ ンを通り抜けた人は，ペルガモンと同様に真正面に大祭 壇そしてその背後にアルテミスの神殿を望むことにな る。

これらの神域では, 神域の全体の形が若干いびっで, 一本の軸線が神域の中央を貫通しているわけでもなく， 建物がこの周囲に完全に左右対称に配置されているわけ でもない。しかしながら計画者の頭の中には，理念とし て完全な軸線計画が存在していたに違いないと思われ る。ごのように斜めに配置することになった理由は，お そらく敷地の条件とすでに建っている建物の位置を変え 


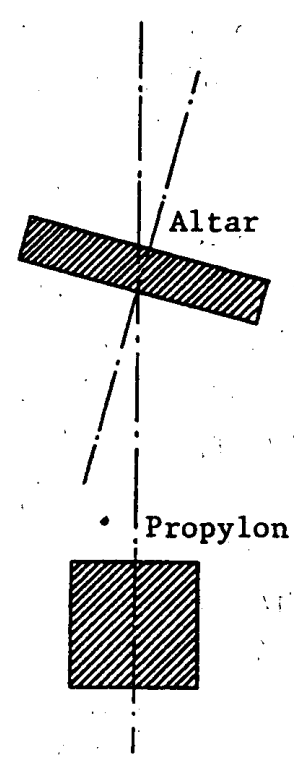

Selinus

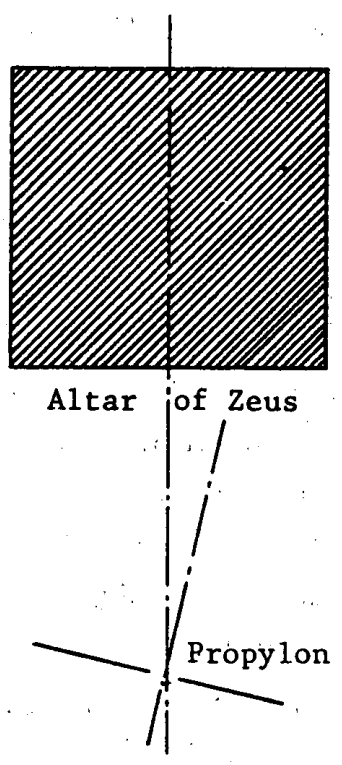

Pergamon
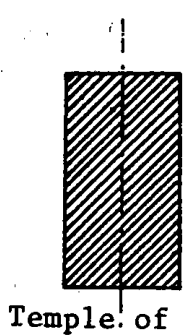
Artemi降

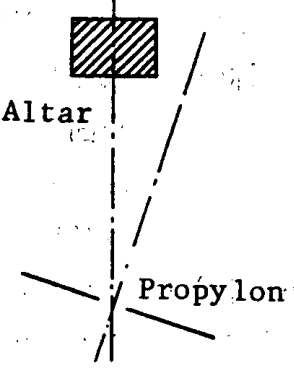

Magnesia

図一3 プロピロンの軸線と建物の軸線が屈折する例

得ないという歴史的な条件によるもの，と解釈される。

2）プロピロンの軸線と建物の出隅部の一致（図一4）

セリヌス・デメテール神殿、前 5 .世紀

ペルガモン・アテナ・ポリアス神殿・前 3 世紀

前述したように，セリヌスのデメデール神域ではプロ ピロンの軸線が祭壇の中央を通っているが, その後ろの 神殿の正面左側の隅もこの軸線上に置かれている。プロ. ピロンを新しくここに建設するとき，神殿と祭壇のどち らを配置の基準として選んだかは不明であるが；いずれ にせよ,プロピロンの軸線は神殿と祭壇の双方とこうし た関係をもっている11。:ペルガモンのアテナ・ポリアス 神域はアクロポリスの上にあるが；神殿は紀元前 3 世紀 に建てられ，周囲を取り囲むストア及びプロピロンがエ ウメネス II世（前 197-159 年）の治世の,ときに建てられ た212!。プロピロンの軸線はここでもまっすぐ神域内を横 切り,アテナ・ポリアス神殿の基壇の南西隅に到ってい る。もっともこの神域の場合, プロピロンから見える神 殿の姿はその正面ではなくその側面であり, 正面性には 欠ける。神殿の正面に向かう位置にプロピロンを配置で きなかったのは，そこにすでに図書館があったこと，そ してそこまで道路が達していなかったという敷地の条件 がその理由と思われる。

3）プロピロンの軸線と建物の外壁線の一致（図一5）

$$
\begin{array}{lll}
\text { プリエネ: } & \text { ゼウス神殿 } & \text { 前 } 3 \text { 世紀 } \\
\text { ペルガモン } & \text { デメテール神殿 } & \text { 前 } 3 \text { 世紀 } \\
\text { プリエネ } & \text { アテナ・ボリアスの祭壇 } & \text { 前 } 1 \text { 世紀 }
\end{array}
$$

プリエネのゼウス神域は，市の中心に位置するアゴラ の東側にある ${ }^{13)}$ 。町全体はいわゆるヒッポダモス式の格 子状の道路網で計画されているので；神域自体の形も矩 形である。神殿およびストアの年代は紀元前 3 世紀とさ

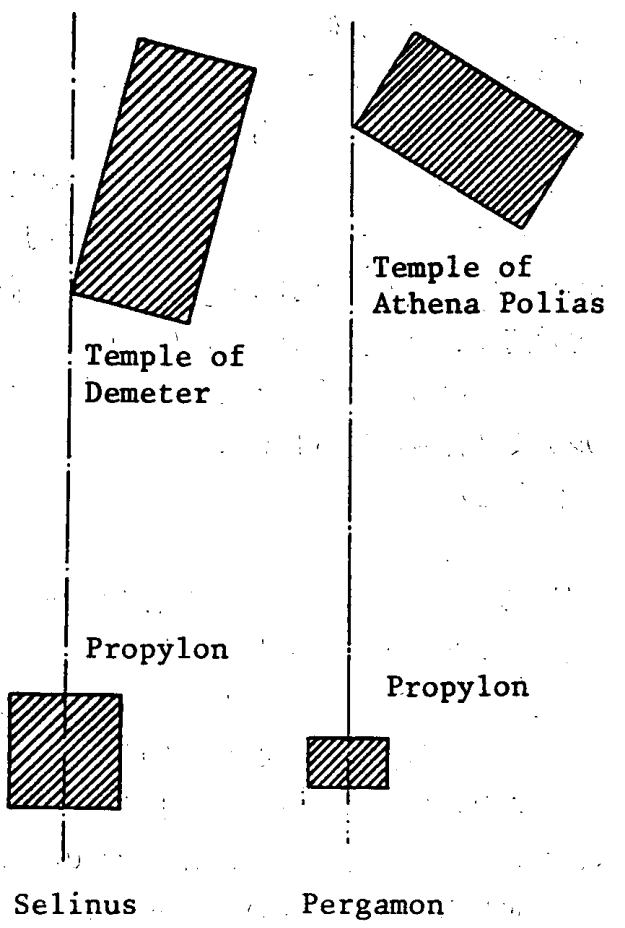

图一4 プロピロンの軸線が建物の隅角部に当たる例

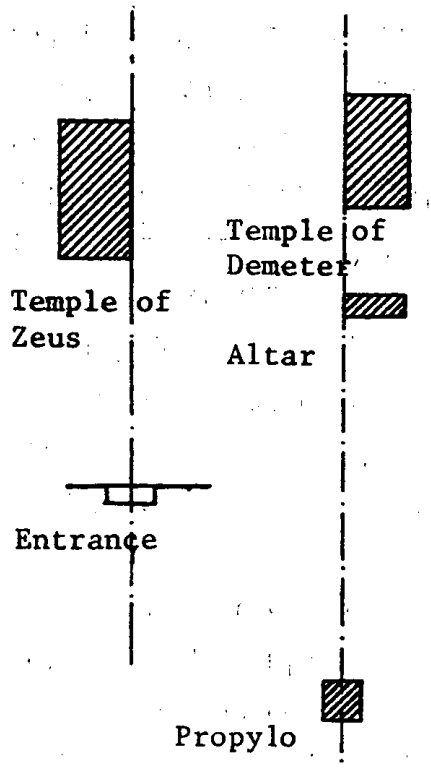

Priene

$$
\text { Pergamon }
$$

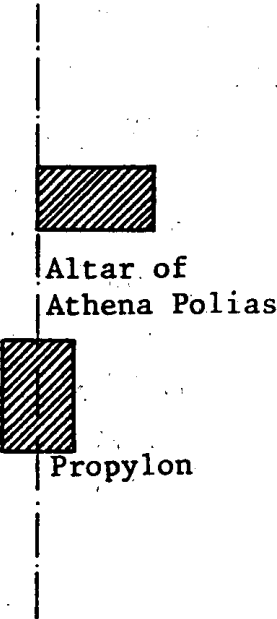

Priene
图一5 プロピロンの軸線と建物の外壁線が重なる例

れる。神域は東側に入り口があり，北，南側にズトアを 配し，前柱式のゼウスの神殿は，その背面を神域の西側 の壁にほぼ接するようにして中心からやや北側に寄せて 建てられている。したがって，神域全体の軸線性は損な われている。この神域ではプロピロンとなる建物はなく， 単に壁が入り口として開いているだけである。しかしな がら入り口の軸線は神殿の北側の外壁の線と一致してお $り$ ，整然とした全体の計画から見てもその位置は明らか に意図的なものと思われる。

同じくプリエネのアテナ・ポリアスの神域でも，その 
プロピロンと祭壇について同様の現象が認められる14)。 神殿は紀元前 4 世紀, 祭壇は前 2 世紀そしてプロピロン はアウグストゥスの時代のものである。ここではプロピ ロンを入ると、一軸線上に祭壇の南側の端があり, 神 殿はその背後に斜めに望まれる。ヘレニズム期にこの同 じ位置にプロピロンの建物ないし入り口があったかどう か不明であるが，プリエネのゼウスの神域の例からして その可能性は十分考えられる。

ペルガモンのデメテール神域は，これらの神域と較べ ると規模が小さく，また神殿の幅と祭壇の幅が等しいと いう違いこそあるが，プロピロンと祭壇あるいは神殿の 位置関係の点では同じである ${ }^{15 !}$ 。神域の年代は紀元前 3 世紀であるが，神殿の正面部分だけローマ期に変更が加 えられている。ここでもプロピロンの軸線は，奥に細長 い神域のほぼ中央に位置する祭壇の左端を通り，さらに その背後の同じ幅の神殿の左端の壁に達している。コリ ントの北の市壁近くにある紀元前 4 世紀に建てられたア スクレピオス神域は神域全体が矩形で, プロピロン, 神 殿及び祭壇がそれぞれ平行な軸線をもっている点でこれ らと非常に類似している ${ }^{16)}$ 。しかしこの神域が上記の 3 例と違う点は, プロピロンの軸線と神殿あるいは祭壇の どの部分も重ならないということである。

\section{5. 神域の軸線計画の他の建築物への影響}

これまで見た神域における，軸線を意識した配置計画 の影響は確実に他の世俗建物にも及んでいる。例えばミ レトスのギムナジウム (前 2 世紀)，同じくミレトスの ブウレウテリオン（前 175-164 年頃）は中央を貫く一本 の軸線を中心に，中庭の周囲に列柱を迴し，正面中央に 前方に飛び出したプロピロンをもった完全な左右対称の 平面をもっている（図一8）。またオニアンスが指摘する ように, アルカイック期から徐々に発展した不規則な配 置をもったアテネのアゴラでさえも，アッタロスのスト ア（紀元前 159-138 年）の配置はへファイストスの神殿 の軸線を基準にした配置を行なっている(図一6 $)^{171 !} \circ: し$ かもこれらは全て紀元前 2 世紀に集中しており，この時 期が建築の配置計画に，完全に左右対称の軸線計画とい う明確な方針が打ち出され，かつ実行された時期となっ ている。

\section{6. ヘレニズム的軸線計画の背景}

以上の上うに，神域の建物の軸線的な配置計画は，紀 元前 2 世紀になってそのもっとも完成した形に到達し た。建築の単体においては, 紀元前 5 世紀にパルテノン が造られギリシア建築の頂点に達したことを考えると， その後からギリシア建築は, ·建物相互間に明確な論理を 求めるという新しい方向を目指して出発しようとしてい たことを物語っているように思われる。その新しい方向

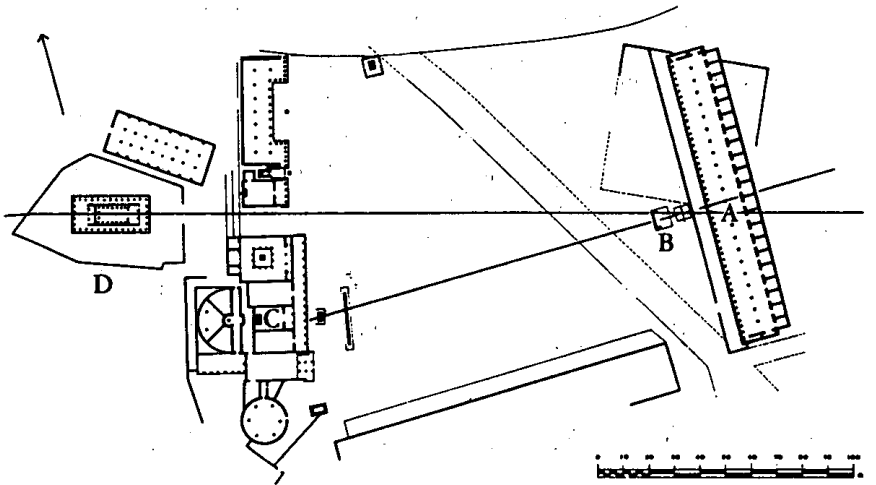

図一6 アテネのアゴラ (A：アッタロスのストア，B：演説台， $\mathrm{C}:$ : トロオ, $\mathrm{D}$ :ヘファイステイオン

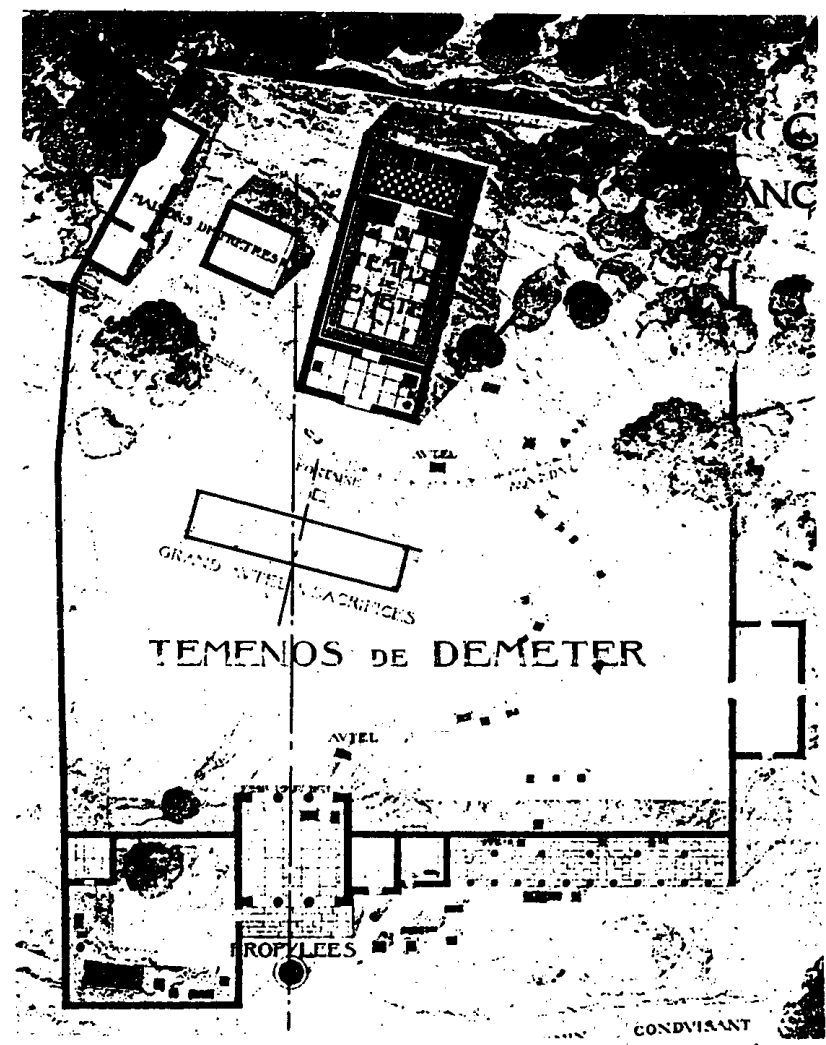

図一7 セリ又スのデメテール神域

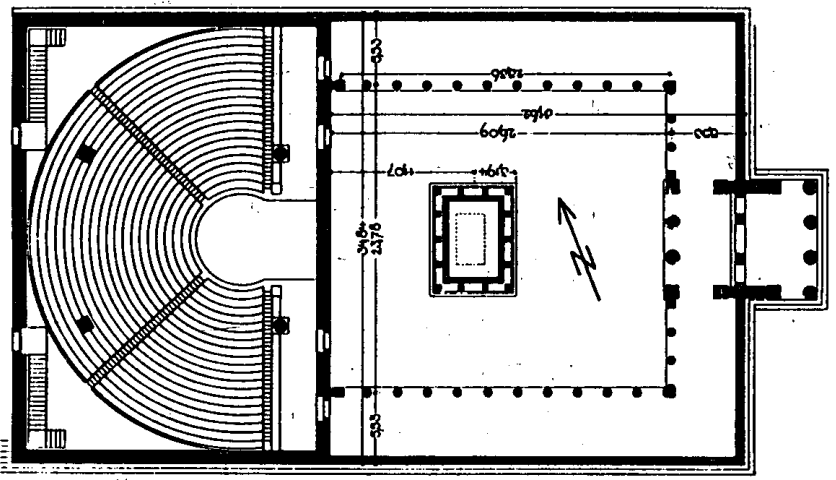

図一8：ミレトスのブウレウテリオン

がはっきりと意識され始めたのは，“神域の配置に関する かぎり；セリヌスのデメテール神域や，コリントのアス クレピオス神域に見られるように，おそらく紀元前 5 世 紀から 4 世紀にかけてであったようだ。 
なぜこのような新しい理念が，神域の配置計画に出現 したかという問題に回答を出すことは容易ではない。紀 元前 4 世紀頃から新しい時代の考え方が起こったことは 当然であるが，それが神域の計画に具体的によ゙のように 影響を及ばしたが実証することは，おそらく不可能に 近い。したがって，ここでは神域の軸線計画の発展を促 したであろう背景を，簡単に整理して述べるごとに止め たい ${ }^{18)}$ 。

その主な背景のひとつは，ヘレニズム期には空間と時 間に関する認識が深くなったことであろう。古代科学は この時期に急速な発展をとげ，ユークリッド（前 300 年 頃）はアレクサンドリアで「幾何学」を書き, 空間とそ れを限定する図形の学問体系を確立した。

またやや遅れてエラトステネス.(前275-194 年頃) は 太陽高度を計測して地球の大きさを計算しており，こう した科学の発達で, それまで漠然と捉えられていた空間 に秩序が与えられかつ組織化されるようになったのであ る。実際，エラトステネスは，地球を経度と緯度という 云次元の座標空間として把握している。こうした空間の 捉え方は, 例えばヒッポダモス式の格子状道路で都市が 計画されているプリエネやマグネジアなどでは, 道路網 が地球の方位に正確に合わせて配置されていることから も説明される。

また例えばアテネには,やはり東西南北の地球の方位 に正確に合わせられた八角形の気象台兼天文台ともいう べき「風の塔（紀元前 1 世紀後半）」，が建設され，そこ では風向の計測さえ行なわれ，当然ながら日時計および 水時計による時間の計測も行なわれた。

蛇足ながらオニアンスによれば，そもそも空間という 言葉 (Space) は，スタディオン'(Stadion) と呼ばれ たギリシアの競争場の名称に語源をもつ ${ }^{19 !}$ 。 1 スタディ オンは元来 $600 \mathrm{ft}$ に相当する長さの単位のことで, この 競争のための長さの単位がそのまま建物の名称となっ た。したがって空間という言葉自体が，単に何もない場 所といった無限定のものでなく，限定されたもの即ち意 図をもって計測されたもの，という意味を内在している のである。

都市や神域のような, 壁で囲まれて明確に限定された 空間に道路や建物の配置によって一つの軸を与えるとい うことは, おそらく, 世界は一つの秩序に基ついた完結 したもの，つまりコスモスだとする考えを現実に視覚化 する試みであったと思われる。したがって神域に中心軸 線を設定するということは，こうした世界に秩序を与え る基準線を設定することにほかならない。とくに，プロ ピロンから神殿にいたる人間の動線が：この軸線にほと んどの場合重なるので, 見学者はこの世界の基準線を強 く意識したであろう。

軸線による神域の配置計画は; 最終的な形として中心
軸に沿った動線上に，階段が付加されることによって劇 的な効果を生み出した。また中心軸上にくる建物の両側 に列柱の翼廊がつくことで, 最大限に強調されることと なった。リンドスのアテナ神域，コスのアスクレピオス 神域の上テラス，そしてペルガモンのゼウスの大祭壇正 面はこの好例である。こうした劇的な空間演出は，高い ポディウムに載せられた神殿，それを四方で取り囲む柱 廊，幅の広い大階段を前面にもつ正面の柱廊などで構成 された，バールベックのようなローマ期の神域にそのま ま受け継がれた。

\section{7. 結語: ギリシア神域における軸線性の発展}

紀元前 6 世紀以前の神域については，プロピロンの軸 線と神殿の軸線を一致させる傾向を認められるような神 域はない20!。これらの神域では，全体の形状さえ整形の ものはなく，それがやっと整形化されたり，建物の直角 配置ないし平行配置がなされるようになるのは，三段階 の発展が見られるアイギナのアファイア神域の最終段階 の神殿（紀元前 500 年頃) $)^{211}$ と，スウニオンのポセイド ン神殿 (紀元前 500 年頃 $)^{22)}$ あたりからである。

神域の配置において, 不完全ながらも軸線性が意識し 始められるのは, 紀元前 5 世紀ころと見てょさそうであ る。その最初の例がセリヌスのデメテール神域であり， 既存の神殿及び祭壇に対して, 斜めになっているが, 亡 もかく軸線性，正面性をかなり意識してプロピロンが配 置されているといっでよい。この紀元前 5 世紀という時 期は, プロピロンの位置だけでなく，アテネのアクロポ リスのプロピライア (紀元前 437-432 年), 同じくアル テミス・ブラウロニアの神域（紀元前 5 世紀）などに見 られるように ${ }^{23)}$, 建物の正面左右に両翼を付加し, 単体 の建物としても軸線性, 正面性を意識しはじめた時期で もある。神殿への人間の動線を問題にせず，神域全体の 形と神殿の位置だけに注目すれば，スパルタのメネライ オン（前 5 世紀）のように を配置するという軸線的な配置計画も，すでにこの時代 に行なわれているのである。またコリントにある紀元前 4 世紀のアスクレピオスの神域も：プロピロンの軸線は 神殿の軸線と平行で，互いにずらされているだけで，正 面性の強調された計画となっている。

ヘレニズム期の神域でも，完全に中心軸線が通り左右 対称の計画がなされたのは，前述したように最終的に紀 元前2世紀になってからである。その例としてメッセネ のアスクレピオ:ス神域 ${ }^{25)}$, 最終段階におけるドドナのゼ

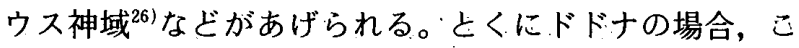
の過渡期の神域の発展が非常に明確に現れており興味深 い。したがって軸線の意識が萌芽した紀元前 5 世紀から， それに基づく完全な左右対称の配置計画が成就された紀 元前 2 世紀までの 300 年間がその移行期間であった。そ 
の間，上で述べたようなプロピロンの軸線と外壁の線を 重殆わせたり，隅角部を重ね合わせたりする軸線のず らし，そして軸線を特殊な点で曲げるという様々な武行 錯誤が行なわれたと言える。

本稿では，発掘報告書の図面をもとにして，建物の相 互関係を軸線という観点から分析した。本来はこれに建 物相互間の距離を調へ，定量的分析をすれば，もっと厳 密な配置における比例関係なども含め，神域全体の設計 手順が解明できるだろうが，オリンピアは別として，報 告書にはそうしたことを可能にする詳しい実測値や縮尺 の大きい平面図がほとんどなく，そのため本稿では定性 的な分析に止めた。

注

1) Ito, J. “Three Sanctuaries in Priene and Magnesia on the Maeander: A Study of Hellenistic Site Planning" Transactions of AIJ, no. 339, pp. 145 153, 1984; _. "The Site Planning of Two Sanctuaries in the Island of Kos" ibid., no. 363, pp. 146 157, 1986; __. "The Planning of Jupiter Sanctuaries at Baalbek : A Study of Roman Site Planning" ibid., no. 377, pp. 106 118, 1987; _ . “The Planning of Two Peristylar Buildings in Olympia and Epidauros : A Study of Architectural Planning in Ancient Greece"ibid., no. 425, pp.113 122, 1991.

2）注 1）のとくに 1984 年の稿参照。

3) Stillwell, R. "The Siting of Classical Greek Temples" Journal of Society of Architectural Historians 13, no. 4, pp. 3 8, 1954 .

4) Wycherley, R.E. "How the Greeks Built Cities" London, pp. 97 100, 1967.

5) Curtius, E. \& Adler, F. "Olympia : Die Ergebnisse der von dem Deutschen Reich versteten Ausgrabung, Karten und Plane" Amsterdam, 1966, rep. Plate VI a-f.この報告書は，オリンピアに関する公刊された発掘 報告としては最も詳細なもので，オリンピア研究の基本 文献である。本文と図版があり，図版だけで全 5 巻から 成り，うち 2 巻が建築, 2 巻が据刻等の出土品, 1 巻が地 図・配置図であり, 発掘された建築及び出土品の現況図, 復元図, 写真など A 2 版の図約 300 枚が収められている。 本稿の分析用資料として，地図・配置図篇の中の 6 枚組 の図面（縮尺 1/320）を用いた。

6) Malwitz, A. “Olympia und seine Bauten" München, 1971. 巻末の平面図。建物が時代別に色分けしてあり, また何年頃建設され何年頃まで使用されたかがすぐ分か る年表が付いている。

7) Herzog, R. and Schatzmann, P. "Kos : Ergebnisse der Deutschen Ausgrabungen und Forschungen, I : Asklepieion” Berlin, Plate 37, 38, 1932. 図版 37 は縮 尺約 $1 / 1100$,及び図版 38 は縮尺約 $1 / 750$ であり, 基本 的には図版 38 を分析に用いた。但し現場確認の結果, 図 版 38 で下ストアの東翼廊と主廊とのなす角度が丁度 90 度として描かれている点は誤りであることが判明し，そ
の点を図版 37 で補った。

8) Hulot, J. and Fougeres, G. “Selinonte : la ville, l'acropole et les temples" Paris, pp. 263 271, 1910.

9) Schrammen, J. "Der Grosse Altar : Der Obere Markt" Die Altertümer von Pergamon, vol. 3, part 1. Berlin, pl. 1, 1906.

10) Humann, C. "Magnesia am Maeander" Berlin, 1904, Blatt 2 参照。また注 1) の拙著 1984 年の稿参照されたい。

11）どちらを基準にしたかということは，実のところはっき りしない。当然神殿の左隅と祭壇の中央を結ぶ線の延長 線上に，プロピロンを配置したとも考えられる。

12) Bohn, R. "Das Heiligtum der Athena Polias" Altertümer von Pergamon vol.2, Berlin, Pl.40, 1885. 参照。

13) Wiegand, Th. and Schrader, H. "Priene" Berlin, pp. 136 147, pl. 13, 1904.

14） op. cit., pp. 81〜135, pl.9. または注 1）の拙著 1984 年 の稿参照されたい。

15) Bohtz, C. H. "Das Demeter-Heiligtum" Altertuimer von Pergamon vol.13, Berlin, 1981.

16) Roebuck, C. "The Asklepieion and Lerna" Corinth vol.14, American School of Classical Studies at Athens, pp. 23 110, Plan A-E, 1951. 参照。

17) Onians, J. "Art and Thought in the Hellenistic Age" London, p. 173, fig. 181, 1979.

18）精しくはオニアンスの前掲書（注 17）を参照されたい。

19) Onians, op.cit. , p. 168.

20）アルカイック期の神域の配置に関しては, ベルギストの 詳細な研究を参照。Bergquist, B. “The Archaic Greek Temenos" Lund, 1967.

21) Welter, G. “Aegina” Athens, fig. 2 4, 1962. 参照。

22) Stais, V. “To Sounion kai Naoi Poseidonos kai Athenas” Athens, 1927. 巻末の配置図参照。

23) Stevens, G.P. “The Periclean Entrance Court of the Acropolis at Athens" Hesperia 5, 1936, pp. 459 470; Travlos, J. "Pictorial Dictionary of Ancient Athens" London, fig. 169, 1971. 参照。

24) Wace, A. J. B. \& Thompson, M.S. "Excavation at Sparta, 1909; The Menelaion" BSA 15, pp. 108 - 116, pl. 5, 1908. 参照。

25) Orlandos, A.K. "H Anaskaphe tes Messenes" Ergon, pp. $79 \sim 82$, fig. 61,1973 . 参照。

26) Evangelidis, D. \& Dakaris, S. "To Ieron tes Dodones : Iera Oikia" Archaiologikes Ephemeris, pp. $1 \sim 193$, fig. 6 9, 1959. 参照。

\section{図版出典}

図一1 注 6) の平面図をもとに著者作製。

図一2 注 7) の, Tafel 37 をもとに著者作製。

図一3,4,5 著者作製。

図一6 注 17）のオニアンスの挿図を転載。

図一7 注 8)，p. 265 の平面図をもとに著者作製。

図-8 Kleiner, G. “Die Ruinen von Milet” Berlin, 1968, Abb. 52.

（1991 年 8 月 21 日原稿受理, 1992 年 2 月 12 日採用決定） 